\title{
Synthesis and recognition properties of colorimetric anion chemosensor bearing 2,4-dinitrophenylhydrazone and indene-1,3-dione moieties
}

\author{
Fatma Aydın \\ Çanakkale Onsekiz Mart University, Department of Chemistry, 17100, Çanakkale, Turkey \\ ${ }^{*}$ Corresponding author at: Çanakkale Onsekiz Mart University, Department of Chemistry, 17100, Çanakkale, Turkey. \\ Tel.: +90.286.2180018. Fax: +90.286.2180533. E-mail address: faydin@comu.edu.tr (F. Aydın).
}

\section{ARTICLE INFORMATION}

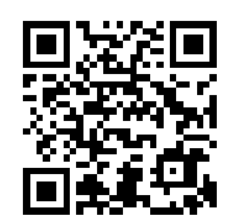

DOI: 10.5155 /eurjchem.5.2.370-373.1032

Received: 06 February 2014

Received in revised form: 01 March 2014

Accepted: 02 March 2014

Online: 30 June 2014

\section{KEYWORDS}

\section{Ninhydrin}

Naked-eye

Anion receptor

UV-Vis titration

Association constant

2,4-Dinitrophenylhydrazine

\section{Introduction}

It is well known that anions play an important role in biological, medical, environmental, catalytic and chemical sciences [1]. In recent years, the development of chemosensors capable of selectively recognizing and sensing anions appears to be particularly attractive [2-7]. There is an increasing attention toward the development of colorimetric probes which have the advantage of showing easily observable color changes in the presence of target guests. Synthetic receptors for anions are usually based on macrocyclic ammonium/ guanidinium [8,9] and imidazolium [10,11], amides [12], sulfonamides [13], carbamates [14], urea/thioureas [15-18], functionalized calixarenes [19], aromatics such as pyrrole, carbazole and indole [20-21] and particularly phenylhydrazone [22], which is a kind of neutral receptor and has a simple synthetic method. Phenylhydrazone derivatives exhibit such an obvious color change when anion is added that one can use naked-eye detection without resorting to spectroscopic instrumentation [23].

In the present work, 2-(2-(2,4-dinitrophenyl)hydrazono) $2 \mathrm{H}$-indene-1,3-dione was synthesized by using nonaqueous ninhydrine and 2,4-dinitrophenylhydrazine in methanol. It was characterized by IR and ${ }^{1} \mathrm{H},{ }^{13} \mathrm{C}$ NMR and MS spectroscopic techniques. It is reported that it could be a highly selective chemosensor for fluoride, cyanide, acetate, hydroxide and hydrogen phosphate anions. As a receptor, it could act as a fluoride ion sensor even in the presence of other halide ions. It is believed that the receptor has a potential application in the future.

\section{Experimental}

\subsection{Reagents and measurements}

All reagents for synthesis were obtained commercially and were used without further purification. In the titration experiments, all the anions were added in the form of their tetra- $n$-butylammonium (TBA) salts, which were purchased from Argoss, Sigma-Aldrich Chemical, stored in a vacuum desiccator containing self-indicating silica, and fully dried before use. Melting points were measured on an Electro Thermal IA 9100 apparatus using a capillary tube. The ${ }^{1} \mathrm{H}$ and ${ }^{13} \mathrm{C}$ NMR spectra were obtained on a Bruker NMR spectrometer operating at 400 and $101.6 \mathrm{MHz}$, respectively. The UV-Visible spectra were recorded using Perkin-Elmer WinLab-25 series spectrophotometer with a quartz cuvette (Path length: $1 \mathrm{~cm}$ ). Infrared absorption spectra were obtained by a Perkin Elmer BX II spectrometer and were reported in $\mathrm{cm}^{-1}$ units. MS spectra were recorded on an Agilent 5973 Inert Mass Selective Detector equipped with Direct Insertion Probe. 
<smiles>[Te][Te][Te]=[Te][Te]</smiles>

Scheme 1<smiles>O=c1c(=NN(O)c2ccc([N+](=O)[O-])cc2[N+](=O)[O-])c(=O)c2ccccc12</smiles>

The color change of the receptor $\left(1.0 \times 10^{-5} \mathrm{M}\right)$ in the absence and the presence of fluoride ions $\left(1.0 \times 10^{-5}\right)$ in DMSO.

Scheme 2

\subsection{Synthesis of 2-(2-(2,4-dinitrophenyl)hydrazono $) 2 \mathrm{H}$ - indene-1,3-dione}

Ninhydrin $(0.890 \mathrm{~g}, 5 \mathrm{mmol})$ in methanol $(20 \mathrm{~mL})$ was added dropwise to a solution of 2,4-nitrophenylhydrazine $(0.990 \mathrm{~g}, 5 \mathrm{mmol})$ in methanol $(30 \mathrm{~mL})$ and the mixture was refluxed by rapidly stirring. The progress of the reaction was monitored by TLC analysis. After the completion of the reaction, for $2 \mathrm{~h}$, the solvent was removed by evaporation. Crude product was washed with ethyl acetate for three times. It was crystallized from tetrahydrofurane as a red crystal. Yield: 1.71 g (82 \%). M.p.: $186-187^{\circ} \mathrm{C}$. FT-IR (KBr, v, cm-1): $3191(\mathrm{~N}-$ H), 3106, 3049 (Caromatic-H), 1728 (C=0), $1678(\mathrm{C}=0), 1540$ ($\mathrm{C}=\mathrm{N}) .{ }^{1} \mathrm{H}$ NMR $\left(400 \mathrm{MHz}, \mathrm{DMSO}-d_{6}, \delta, \mathrm{ppm}\right): 14.51(\mathrm{~s}, 1 \mathrm{H}, \mathrm{NH})$, $8.96\left(\mathrm{~s}, 1 \mathrm{H}, \operatorname{Ar}\left(\mathrm{NO}_{2}\right)_{2}-\mathrm{H}\right), 8.65\left(\mathrm{~d}, 1 \mathrm{H}, \operatorname{Ar}\left(\mathrm{NO}_{2}\right)_{2}-\mathrm{H}\right), 8.32(\mathrm{~d}, 1 \mathrm{H}$, $\left.\operatorname{Ar}\left(\mathrm{NO}_{2}\right)_{2}-\mathrm{H}\right), 8.08(\mathrm{~d}, 2 \mathrm{H}, \mathrm{Ar}-\mathrm{H}), 8.03(\mathrm{~d}, 2 \mathrm{H}, \mathrm{Ar}-\mathrm{H}) .{ }^{13} \mathrm{C}$ NMR $\left(100 \mathrm{MHz}, \mathrm{DMSO}-d_{6}, \delta, \mathrm{ppm}\right): 186(\mathrm{C}=0), 184(\mathrm{C}=0), 142(\mathrm{C}=\mathrm{N})$, $141,139,138,136,133,130\left(\left(\mathrm{NO}_{2}\right)_{2}-\mathrm{Ph}-\mathrm{C}\right), 123,122,117$ (ArC). Anal. calcd. for $\mathrm{C}_{15} \mathrm{H}_{8} \mathrm{~N}_{4} \mathrm{O}_{8}$ : C, 52.95; H, 2.37; N, 16.47; 0, 28.21. Found: C, 52.63; H, 2.26; N, 16.55; 0, 28.26\%. MS (m/z): $340.04\left(\mathrm{M}^{+}\right)$.

\section{Results and discussion}

Here, 2-(2,4-dinitrophenyl)hydrazono) $2 \mathrm{H}$-indene-1,3dione was successfully synthesized from ninhydrin and 2,4dinitrophenylhydrazine and examinated for its anion binding abilities by UV-Vis absorption spectroscopy in DMSO (Scheme 1).

\subsection{Spectral titrations}

The anion binding and sensing properties of 2-(2- $(2,4-$ dinitrophenyl)hydrazono) $2 \mathrm{H}$-indene-1,3-dione were studied by using UV-Vis and ${ }^{1} \mathrm{HNMR}$ spectroscopic titration techniques. Firstly, stock solution of the title compound $\left(1.0 \times 10^{-5} \mathrm{M}\right)$ and that of the tetrabutyl ammonium salts $\left(1.0 \times 10^{-5} \mathrm{M}\right)$ of various anions ( $\mathrm{F}^{-}, \mathrm{Cl}^{-}, \mathrm{Br}-\mathrm{I}^{-}, \mathrm{CN}^{-}, \mathrm{OH}^{-}, \mathrm{OAc}^{-}$and $\mathrm{H}_{2} \mathrm{PO}_{4}^{-}$) were prepared in freshly purified dimethylsulfoxide. Then, $2 \mathrm{~mL}$ stock solution of the compound and $2 \mathrm{~mL}$ stock solution of each anion salt were taken in a $5 \mathrm{~mL}$ volumetric flask and the absorption spectrum of the resulting solutions were recorded (Figure 1). The dimethylsulfoxide solution of receptor is of a greenish yellow color and exhibits a strong absorption band at $416 \mathrm{~nm}$ due to the $\pi \rightarrow \pi^{*}$ transition. Upon addition of anions such as $\mathrm{F}$-, $\mathrm{OH}^{-}, \mathrm{CN}^{-}, \mathrm{OAc}^{-}$and $\mathrm{H}_{2} \mathrm{PO}_{4}^{-}$to host solution resulted in a noteworthy change in the visible region of the spectrum (approximately $90 \mathrm{~nm}$ red shift), which could be detected by the color change from greenish yellow to purplish blue by the 'naked-eye'. In contrast, no color changes were observed upon addition of $\mathrm{Cl}^{-}, \mathrm{Br}^{-}$, and I- (Figure 2). This shift is suspected to be a result of the deprotonation of the tautomeric extended $\pi$ conjugated network including the inden-1-ol moiety and the hydrazo linker, and the pronounced color change is a result of that phenomenon, but not hydrogen bonding (Scheme 2).

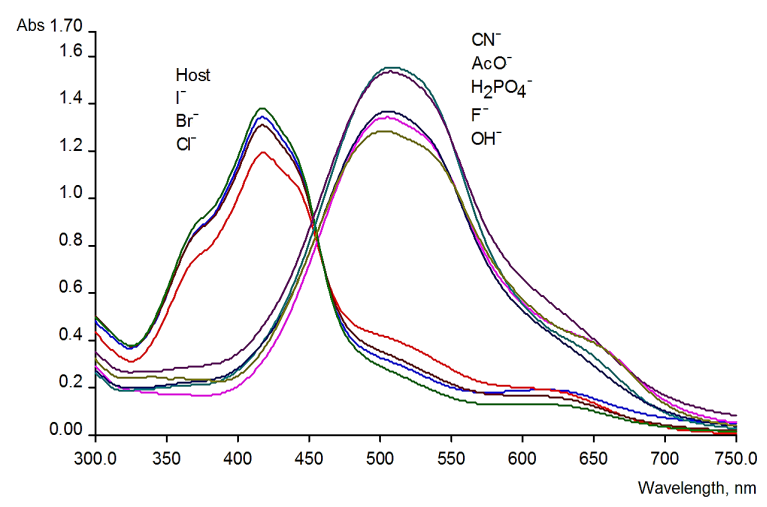

Figure 1. UV-visible spectra of named compound with [Bu$\left.{ }_{4} \mathrm{~N}\right] \mathrm{X}(\mathrm{X}: \mathrm{F}, \mathrm{Cl}, \mathrm{Br} \mathrm{I}$ $\mathrm{CN}, \mathrm{AcO}, \mathrm{H}_{2} \mathrm{PO}_{4}$ and $\mathrm{OH}$ ) at 1:1 ratio in DMSO: $\mathrm{H}_{2} \mathrm{O}$ 95:5 (v:v) solution.

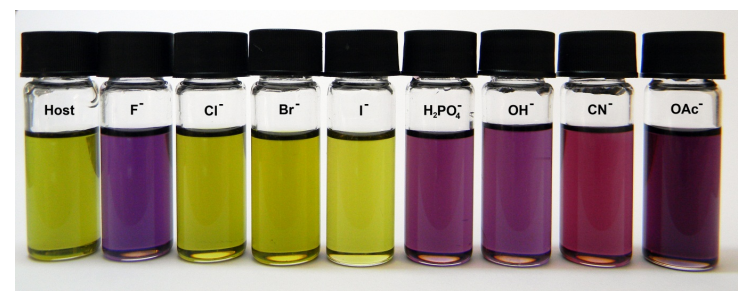

Figure 2. Colour change observed upon the addition of TBA salts to a DMSO: $\mathrm{H}_{2} \mathrm{O}, 95: 5$ (v:v) solution left to right $\mathrm{F}, \mathrm{Cl}, \mathrm{Br}, \mathrm{I}^{-}, \mathrm{H}_{2} \mathrm{PO}_{4}, \mathrm{OH}^{-}, \mathrm{CN}^{-}$and OAc:

Secondly, binding ability of the receptor for $\mathrm{F}^{-}$was investigated by UV-Vis spectroscopy in dimethylsulfoxide using a constant host concentration $\left(1.0 \times 10^{-5} \mathrm{M}\right)$ and increasing the F- concentrations ( $0-4$ equiv.). Upon the addition of $\mathrm{F}$ - to the host solution, the intensity of the absorption peak at $416 \mathrm{~nm}$ 
disappeared gradually and a new band at $506 \mathrm{~nm}$ appeared in UV-Vis spectrum of the receptor solution. At the same time, the color of the receptor solution also changed from greenish yellow to purplish blue (Figure 3) with only one well-defined isosbestic point $448 \mathrm{~nm}$, indicating the formation of a stable complex between the receptor and F- during the course of the titration. While gradually increasing the fluoride ion concentrations, the corresponding changes in absorbance intensities at $506 \mathrm{~nm}$ were plotted against anion concentrations. By nonlinear least-squares fitting of the spectroscopic titration curves at $\lambda_{\max } 416 \mathrm{~nm}$ for the receptor, the association constant Kass of the complex between the receptor and $\mathrm{F}^{-}$was calculated as $56.43 \times 10^{3} \mathrm{M}^{-1}(r=0.9960)$ (Figure 3). The large bathochromic shift (from 416 to $506 \mathrm{~nm}$ ) could be explained by the deprotonation of tautomeric azoinden-1-ol moiety and the electron-deficient $o$ - and $p-\mathrm{NO}_{2}$ moiety by the anion through hydrogen bonding.

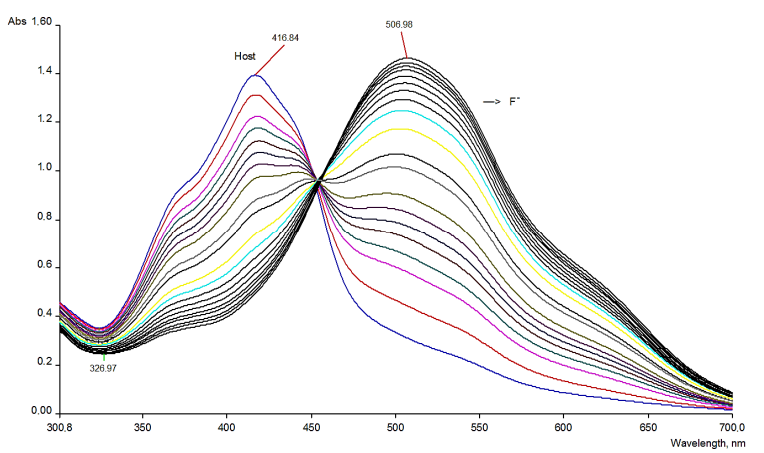

Figure 3. Titration of $1.0 \times 10^{-5} \mathrm{~mol} / \mathrm{L}$ solution of receptor with a standard solution of F- (as tetrabutylammonium salt) in DMSO: $\mathrm{H}_{2} \mathrm{O}, 95: 5$ ( $v: \mathrm{v}$ ) solution at $298.2 \pm 0.1 \mathrm{~K}$.

Affinity constants for the complexations between receptor and anionic species, which were shown in Table 1 , were determined by non-linear fitting analyses of the titration curves according to 1:1, host-guest complex stoichiometry [24]. Obviously shown in Table 1 , the selectivity trends of binding affinities of anions to the reseptor were determined to be $\mathrm{AcO}^{-}$ $>\mathrm{CN}^{-}>\mathrm{OH}^{-}>\mathrm{H}_{2} \mathrm{PO}_{4}^{-}>\mathrm{F}^{-}>\mathrm{Cl}^{-} \sim \mathrm{Br}^{-} \sim \mathrm{I}^{-}$.

Table 1. Association constants $K_{\text {ass }}$ of the receptor with anions in DMSO: $\mathrm{H}_{2} \mathrm{O}$, 95:5(v:v) solution at $298.2 \pm 0.1 \mathrm{~K}$.

\begin{tabular}{|c|c|}
\hline Anion & $K_{\text {ass }}(\mathrm{L} / \mathrm{mol}) \times 10^{3}$ \\
\hline F- & 5.64 \\
\hline $\mathrm{Cl}^{-}$ & ND* \\
\hline $\mathrm{Br}^{-}$ & ND * \\
\hline I & ND * \\
\hline $\mathrm{CN}^{-}$ & 14.05 \\
\hline $\mathrm{OAc}^{-}$ & 13.70 \\
\hline $\mathrm{OH}^{-}$ & 8.06 \\
\hline $\mathrm{H}_{2} \mathrm{PO}_{4}^{-}$ & 8.12 \\
\hline
\end{tabular}

The stoichiometry of the host-guest complex forming between azo-inden-1-ol compound and fluoride anion for determination of stoichiometry of the host-guest complex was determinated by the continuous variation method (Job's Plot). When the molar fraction of the guest is $\sim 0.5$, the absorption reaches a maximum, demonstrating that the receptor formed a 1:1 complex with fluoride anion (Figure 4).

Thirdly, further insights to the nature of receptor and $\mathrm{F}^{-}$ interactions were investigated by ${ }^{1} \mathrm{H}$ NMR titration experiment in DMSO- $d_{6}$ solution (TMS was used as an internal standard). A $1.0 \times 10^{-3} \mathrm{M}$ solution of the named compound in DMSO- $d_{6}$ was prepared. Then, the increased amount of fluoride anion from tetrabutyl ammonium salt, (1.0 equiv. DMSO- $\left.d_{6}\right)$ was added to the solution mentioned above in gradually increased amounts and ${ }^{1} \mathrm{H}$ NMR spectra of the host-guest system were obtained. Upon addition of $\mathrm{F}^{-}$, the peak at $14.51 \mathrm{ppm}$, which was assigned to the keto-hydrazo tautomeric N-H proton, shifted downfield and finally disappeared, indicating the deprotonation of the this tautumeric moiety between reseptor and by F- (Figure 5). In addition, the slight down-field shifts of the aromatic proton signals were also found.

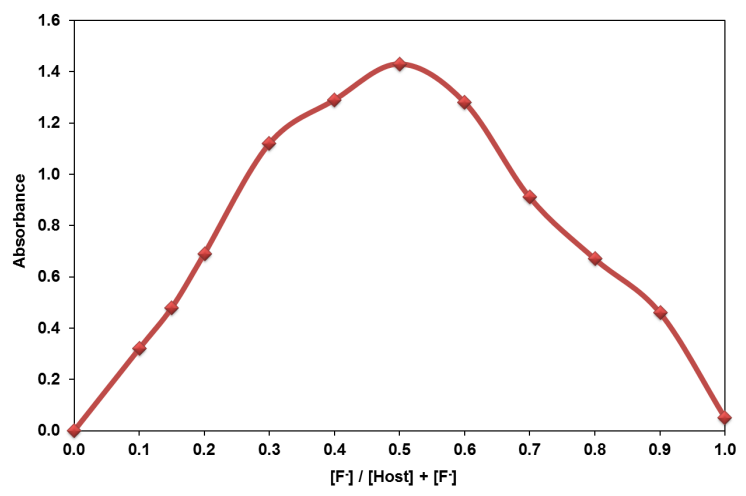

Figure 4. Job's of azo-hydrazo form (at $416 \mathrm{~nm}$ ) with $\mathrm{F}^{-}$anion. The total concentration of the host and guest is $1.0 \times 10^{-5} \mathrm{~mol} / \mathrm{L}$ in DMSO: $\mathrm{H}_{2} \mathrm{O}, 95: 5(v: v)$ solution.

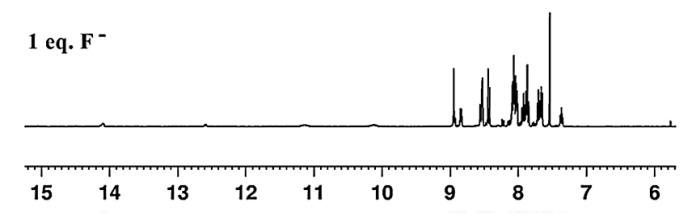

Free

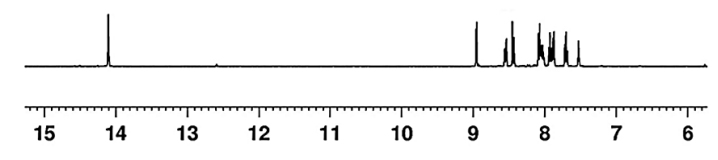

Figure 5. ${ }^{1} \mathrm{H}$ NMR spectrum (DMSO- $d_{6}$ ) of 2-(2-(2,4-dinitrophenyl) hydrazono) $2 \mathrm{H}$-indene-1,3-dione in the absence and presence of $\mathrm{F}$ - (1 equiv. F-).

\section{Conclusion}

2-(2-(2,4-Dinitrophenyl)hydrazono) $2 H$-indene-1,3-dione was developed as a new chromogenic anion receptor which bears a hydrazone moiety which has with dinitro phenyl and inden-1-ol moiety as a signaling group. It was proved to detect the fluoride anion with a higher affinity than other halide anions such as chloride, bromide and iodine. As a colorimetric anion receptor, the solution color changes significantly after the addition of fluoride, cyanide, hydroxide, acetate and hydrogen phosphate anions. The results showed that the tautomeric azo-inden-1-ol hydrogen of this receptor could easily be deprotonated by strongly basic anions such as $\mathrm{AcO}^{-}, \mathrm{F}^{-}$, $\mathrm{CN}^{-}, \mathrm{OH}^{-}$and $\mathrm{H}_{2} \mathrm{PO}_{4}^{-}$. Thus, it is easy to distinguish these anions. Such a naked-eye observation method is fast, simple, and convenient. As a result, this compound can be used as a chemical sensor for these anionic species.

\section{Acknowledgements}

This work was supported by the Çanakkale Onsekiz Mart University Research Fund (Project No: BAP-2010-57).

\section{References}

[1]. Beer, P. D.; Gale, P. A. Angew. Chem. Int. Ed. 2001, 40, 486-516.

[2]. Gale, P. A. Coord. Chem. Rev. 2001, 213, 79-128. 
[3]. Gale, P. A. Coord. Chem. Rev. 2003, 240, 191-221.

[4]. Li, J.; Lin, H.; Lin, H. J. Coord. Chem. 2009, 62(12), 1921-1927.

[5]. Athikomrattanakul, U.; Promptmas, C.; Katterle, M. Tetrahedron Lett. 2009, 50, 359-362.

[6]. Shao, J.; Lin, H.; Lin, H. Dyes and Pigments 2009, 80, 259-263.

[7]. Inoue, Y.; Kanbara, T.; Yamamoto, T. Tetrahedron Lett. 2003,44, 51675169.

[8]. Best, M. D.; Tobey, S. L.; Anslyn, E. V. Coord. Chem. Rev. 2003, 240, 315.

[9]. Lu, Q. S.; Dong, L.; Zhang, J.; Li, J.; Jiang, L.; Huang, Y.; Qin, S.; Hu, C. W.; Yu, X. Q. Org. Lett. 2009, 11(3), 669-672.

[10]. Shao, J.; Qiao, Y. H.; Lin, H.; Lin, H. J. Lumin. 2008, 128, 1985-1988.

[11]. Esteban-Gomez, D.; Fabbrizzi, L.; Licchelli, M. J. Org. Chem. 2005, 70, 5717-5720.

[12]. Bondy, C. R.; Loeb, S. Coord. Chem. Rev. 2003, 240, 77-99.

[13]. Li, J.; Chen, H.; Lin, H.; Lin, H. J. Photochem. Photobiol. B 2009, 97, 1821.

[14]. Chen, Q. Y.; Chen, C. F. Tetrahedron Lett. 2004, 45, 6493-6496.

[15]. Adminal, D. J.; Krishna, D. K.; Ganguly, B.; Das, A. Org. Lett. 2004, 6(20), 3445-3448.

[16]. Aydin, F.; Tunoglu, N.; Aykac, D.; Arslan, N. B.; Kazak, C. Turk. J. Chem. 2012, 36(5), 764-777.

[17]. Lee, K. H.; Hong, J. I. Tetrahedron Lett. 2000, 41, 6083-6087.

[18]. Beer, P. D.; Gale, P. A.; Hesek, D. Tetrahedron Lett. 1995, 36, 767-770.

[19]. Cafeo, G.; Kohnke, F. H.; White, A. J. P.; Garozzo, D.; Messina, A. Chem. Eur. J. 2007, 13, 649-656.

[20]. Dydio, P.; Zieliniski, T.; Jurczak, J. J. Org. Chem. 2009, 74, 1525-1530.

[21]. Shao, J.; Wang, Y.; Lin, H.; Li, J.; Lin, H. Sens. Actuators B, Chem. 2008, 134, 849-853.

[22]. Shao, J.; Lin, H.; Yu, M.; Cai, Z.; Lin, H. Talanta 2008, 75, 551-555.

[23]. Li, J.; Wang, Y.; Lin, H.; Lin, H. J. Incl. Phenom. Macrocycl. Chem. 2009, 63, 281-285.

[24]. Bourson, J.; Pouget, J.; Valeur, B. J. Phys. Chem. 1993, 97, 4552-4557. 